\title{
Quantitative bacteriology-A predictor of risk of postoperative infection in open fractures
}

\author{
Arthi $\mathbf{K}^{1}$, Deepa $\mathbf{R}^{2, *}$, Mangala $\mathbf{A}^{3}$ \\ ${ }^{\mathbf{1}}$ Assistant Professor, Dept. of Microbiology, Meenakshi Ammal Dental College, Chennai, Tamil Nadu, ${ }^{\mathbf{2}}$ Associate Professor, \\ Dept. of Microbiology, Government Villupuram Medical College, Tamil Nadu, ${ }^{3}$ Director, Dept. of Microbiology, Madurai \\ Medical College, Tamil Nadu, India
}

*Corresponding Author:

Email: arthikrao82@gmail.com

Received: $21^{\text {st }}$ June, 2018

Accepted: $24^{\text {th }}$ August, 2018

\begin{abstract}
Introduction: Quantitative Microbiology involves measurement of an absolute quantity of bacteria per unit of volume. The threshold to distinguish colonisation from infection is $10^{5} \mathrm{CFU} / \mathrm{g}$. Quantitative cultures are used in predicting the risk of post operative infection.

Aim: To determine the role of quantitative bacteriology as a predictor of risk of infection in patients with open fractures.

Materials and Methods: One hundred patients who had sustained open fractures of long bones were included in the study. During debridement before antiseptic wash, a piece of tissue (muscle/skin) was collected under aseptic precautions for quantitative culture. A quantitative count of $\geq 10^{4} \mathrm{cfu} / \mathrm{gm}$ was interpreted as significant microbial burden. These patients were followed up for 6 weeks for development of clinical signs of infection and two swabs were collected by Levine's technique for semiquantitative culture.

Results: The preoperative culture of the debrided tissue of $41 \%$ yielded a microbial load of $\geq 10^{4}$ cfu/gram among which $85.3 \%$ had $10^{5} \mathrm{cfu} / \mathrm{gram}$ of microbial load. Polymicrobial growth was reported in $12.2 \%$ of patients. Postoperatively $39 \%$ developed signs of infection Seventy one percent of patients with $10^{5} \mathrm{cfu} / \mathrm{gram}$ of microbial load in the preoperative period developed postoperative infection. All patients with polymicrobial growth in the preoperative debridement cultures with $\geq 10^{4} \mathrm{cfu} / \mathrm{gm}$ of microbial load, developed infection in the postoperative period.

Conclusion: Quantitative Microbiology plays a precise role in predicting the risk of infection as it is valuable in estimating the bacterial bioburden. Polymicrobal etiology can lead to clinical infection if not managed effectively.
\end{abstract}

Keywords: Quantitative, Infection, Bioburden, Fracture, Debridement.

\section{Introduction}

Fractures have been described as medical problems throughout history as the vascular supply to the bone is the basis for healing and treatment of soft tissue infections, is a challenge. Thorough debridement and lavage of the wound along with antibiotic prophylaxis forms the mainstay of management in these patients. Treatment should be directed towards achieving healing of the soft tissues and bone with the fewest complications.

Microbiological assessment can be done using qualitative, semi-quantitative or quantitative methods. As the quantitative count measures the absolute number of bacteria it is presumed to have a direct relationship between the bio-burden on the surface to the risk of invasion, deeper infection, bacteremia and sepsis. This threshold of bacterial count can predict possible clinical outcomes. $10^{5} \mathrm{CFU} / \mathrm{g}$ is commonly used as the threshold for distinguishing between colonisation and infection. ${ }^{1}$

However, Breidenbrach and Trager have shown that, a critical level of $\geq 10^{4}$ bacteria should be achieved to cause infection in the wounds and quantitative cultures are effective in predicting the likelihood of infection than swab cultures. The $10^{4} \mathrm{cfu} / \mathrm{g}$ of tissue suggests that the microorganism has the potential to cause infection if sustained at or above this level. In an acute wound, infection occurs as the microbial burden increases with the multiplying bacteria. ${ }^{2}$

This study was aimed to detect the efficiency of quantitative cultures in predicting the risk of post operative infection in patients who had sustained compound fractures of the limbs.

\section{Materials and Methods}

This prospective study was done for a period of 6 months from June to December 2016.One hundred adult patients who presented with open fracture of limbs and who were hemodynamically stable for whom emergency debridement and fixation were performed were included in the study. Informed consent from patients and approval from Institutional Ethics Committee were obtained.

Sample Collection: Under aseptic precautions a piece of tissue (muscle/skin) was taken immediately after debridement in the Emergency theatre before antiseptic wash. The tissue sample was immediately transported to the laboratory and processed for culture.

\section{Pre operative Period- Quantitative Culture of Tissue} during Debridement. ${ }^{3}$

The container with the piece of tissue was weighed on an analytical balance. The weight of the empty 
specimen container was deduced to determine the final weight of the tissue in grams or milligrams. Under aseptic precautions, the tissue was, placed in a sterile petri dish, and homogenized using a sterile scalpel. It was then transferred to $5 \mathrm{ml}$ of sterile $0.85 \%$ sodium chloride to yield a 1:5 dilution. The homogenate was vortexed for 30 seconds and $0.1 \mathrm{ml}$ plated onto $5 \%$ Sheep Blood agar plate (BAP) and labelled as $10^{-1}$. A loopful of tissue homogenate was subjected to Gram Staining and observed for the presence of pus cells and organisms. Serial dilutions of the homogenate were performed to yield $10^{-2}, 10^{-3}, 10^{-4}$ dilutions and $0.1 \mathrm{ml}$ of each dilution was inoculated onto BAP and incubated at $37^{\circ} \mathrm{C}$ for 24 hours.

The number of organisms per gram of tissue was determined by counting the colonies on the plate that grew between 30 and 300 colonies. The total number of organisms was calculated by using the colony count times the dilution factor (using 5 as the factor for the homogenate dilution). A microbial load of $\geq 10^{5} \mathrm{cfu} / \mathrm{gm}$ was considered significant.

CFU x Homogenate dilution x Plate dilution Weight of the tissue

Post operative Period-Collection of Pus/discharge from Surgical Site Wound. ${ }^{4}$

All the patients were observed for a period of 6 weeks post operatively for clinical signs and symptoms of infection such as redness, warmth or purulent discharge. Under aseptic precautions, purulent discharge from surgical site was collected by Levine's technique by rolling two swabs over a $1 \mathrm{~cm}^{2}$ area on the wound with sufficient pressure to extract the exudate and transported immediately to the Microbiology laboratory. One swab was used to prepare smears for
Gram staining and the other swab was plated onto $5 \%$ sheep BAP and Mac Conkey agar in four quadrants. The plates were incubated at $37^{\circ} \mathrm{C}$ for 24 hours and examined for the presence of bacterial growth.

Identification and antimicrobial susceptibility testing of bacterial isolates was done by standard microbiological methods $s^{5,6}$

\section{Results}

One hundred patients presenting with open fractures in the age group of $18-60$ years were studied. The preoperative culture of the debrided tissue of 41 patients $(41 \%)$ [Chart 1] yielded a microbial load of $\geq 10^{4} \mathrm{cfu} / \mathrm{gram}$ among which 35 patients had $10^{5}$ cfu/gram of microbial load [Table 1]. Monomicrobial growth was observed in 37 of 41 patients $(87.8 \%)$ and polymicrobial growth in 5 of 41 (12\%).

On follow up of the patients for a period of 6 weeks following surgery, 39 of 100 patients (39\%) developed signs of infection. Twenty seven of $39(69.2 \%)$ had a bacterial growth on culture [Table 2]. Monomicrobial growth was observed in 22 of 27 patients $(81.4 \%)$ and polymicrobial growth in 5 of 27 patients $(18.5 \%)$ [Table 3].

Analysis of the preoperative and postoperative culture results showed that 25 out of 35 patients (71.4\%) with a $10^{5} \mathrm{cfu} / \mathrm{gram}$ of microbial load in the preoperative period developed post operative infection. [Table 2]. Poly microbial growth was found in 5/25 patients and all 5 patients with $\geq 10^{4} \mathrm{cfu} / \mathrm{gm}$ of microbial load, developed infection in the postoperative period. [Table 3].

\section{Chart 1: Analysis of debridement cultures}

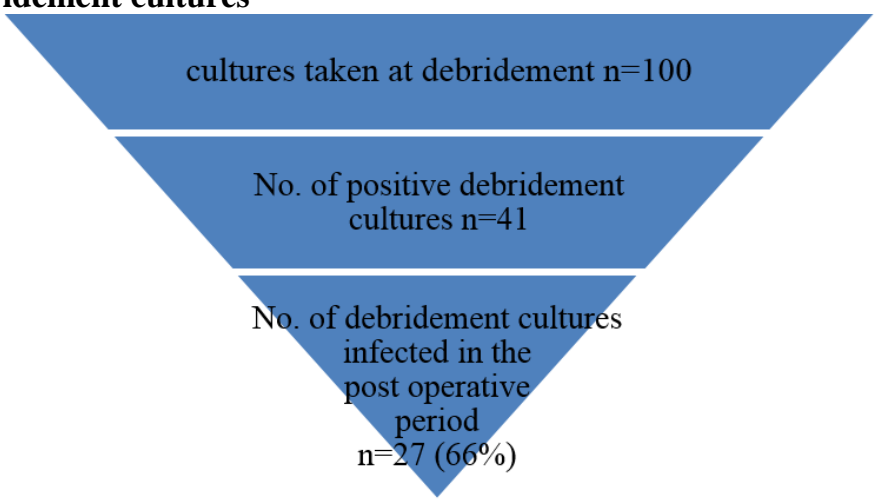

Table 1: Comparison of tissue count and organisms reported in debridement cultures

\begin{tabular}{|l|c|c|}
\hline Tissue count $(\mathbf{c f u} / \mathbf{g m})$ & $\begin{array}{c}\text { No. of significant debridement } \\
\text { cultures }(\mathbf{n = 4 1})\end{array}$ & Percentage $\%$ \\
\hline $10^{4}$ & 2 & 5 \\
\hline $10^{5}$ & 35 & 85.3 \\
\hline $10^{6}$ & 3 & 7 \\
\hline $10^{7}$ & 1 & 2 \\
\hline
\end{tabular}

$\mathrm{Cfu} / \mathrm{gm}$ - colony forming units per gram 
Table 2: Correlation of quantitative bacterial count in debrided tissue and post operative infection

\begin{tabular}{|l|c|c|}
\hline \multicolumn{2}{|c|}{ Preoperative - debrided tissue } & Postoperative - pus culture \\
\hline Quantitative count (cfu/gm) & $\begin{array}{c}\text { No. of significant } \\
\text { debridement cultures }(\mathbf{n = 4 1 )}\end{array}$ & $\begin{array}{c}\text { Post operative infection } \\
(\mathbf{n = 2 7})\end{array}$ \\
\hline $10^{4}$ & 2 & $1(50 \%)$ \\
\hline $10^{5}$ & 35 & $25(71 \%)$ \\
\hline $10^{6}$ & 3 & $1(33 \%)$ \\
\hline $10^{7}$ & 1 & - \\
\hline
\end{tabular}

Table 3: Correlation of polymicrobial growth in debridement cultures and post operative infection

\begin{tabular}{|c|c|c|}
\hline \multicolumn{2}{|c|}{ Preoperative period } & Post operative period \\
\hline Microbial load & $\begin{array}{c}\text { No. of patients with } \\
\text { polymicrobial growth }\end{array}$ & $\begin{array}{c}\text { No. of patients with polymicrobial } \\
\text { growth }\end{array}$ \\
\hline$\geq 10^{4} \mathrm{cfu} / \mathrm{gram}$ & $5(12 \%)$ & $5(18.5 \%)$ \\
\hline
\end{tabular}

\section{Processing of Tissue for Quantitative Culture}

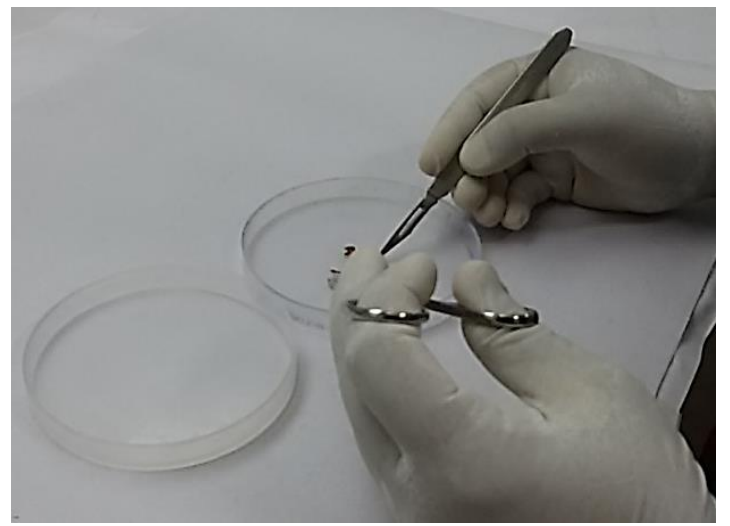

Fig. 1: Homogenisation of tissue using sterile scalpel and petri dish

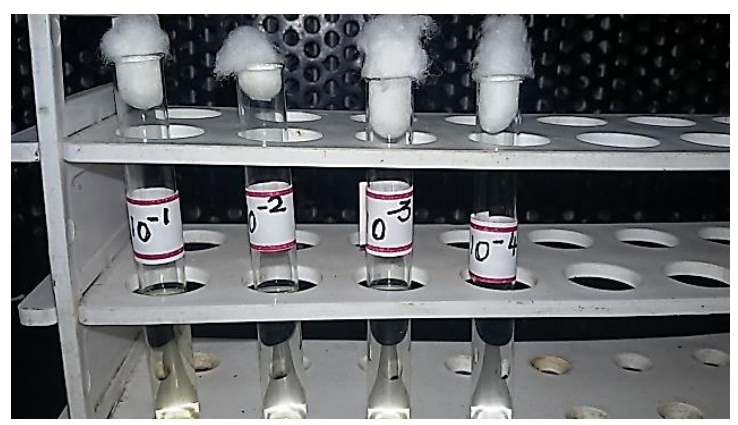

Fig. 2: Serial dilution for quantitative culture

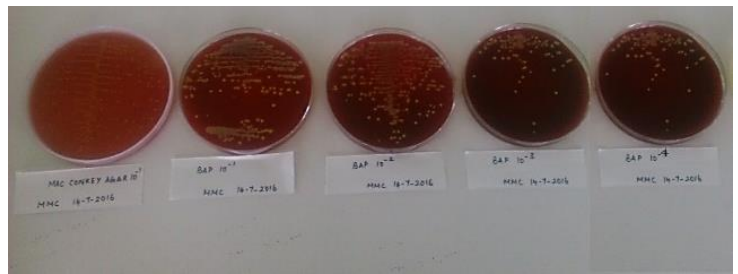

Fig. 3: Quantitative culture on 5\% sheep blood agar

\section{Discussion}

All open wounds are usually considered to be contaminated with microorganisms. More so, when the wound bed becomes necrotic, it favours microbial proliferation. ${ }^{7}$ Bacterial contamination of open fractures is reported to occur in $60-70 \%$ of cases which may be responsible for the infectious complications in these patients. Wound debridement as soon as possible after the injury is recommended as the standard of care for all compound fracture wounds. ${ }^{8}$

Among the stages of development of wound infection, critical colonization is the stage where bacteria in the wound are at a critical level and have adhered, multiplied and caused a delay in wound healing. A piece of deep tissue collected at the time of debridement after cleansing all the superficial debris is considered the most valuable method for determining the bacterial bioburden in the wound.

In this study, the debridement culture was done by collecting a tissue bit, performing Gram's stain and culturing by quantitative method. A quantitative count of $\geq 10^{4} \mathrm{cfu} / \mathrm{gm}$ was taken as the significant microbial burden which must be reached to cause infection in the post-operative period as proposed by Breidenbach and Trager. ${ }^{2}$ This was observed in $41 \%$ of the debridement cultures among which $12.2 \%$ showed polymicrobial growth.

Quantitative microbiology has a definitive role to play in wound management as it is reliable in predicting the risk of infection and wound healing. ${ }^{7}$ In this study, analysis of the samples was done to correlate the preoperative microbial load in tissues to the development of infection. Seventy one percent of patients with a quantitative count of $10^{5} \mathrm{cfu} / \mathrm{gm}$ developed infection later on and $33 \%$ with a count of $10^{6} \mathrm{cfu} / \mathrm{gm}$ developed post-operative infection. One patient who had a tissue count of $10^{7} \mathrm{cfu} / \mathrm{gm}$ did not develop infection, probably because of his young age, absent co-morbid conditions, a healthy immune system and good response to antibiotic treatment [Table 2]. It is notable that a study conducted in 1988 at the Case Western Reserve University to examine various factors that might have an impact upon infection rate in patients with open fractures observed that on quantitative culture, all patients with a tissue count of 
$10^{4} \mathrm{cfu} / \mathrm{gm}$ developed infection, while one third of patients with a count of $10^{5} \mathrm{cfu} / \mathrm{gm}$ became infected. ${ }^{9}$

Microbial synergy increases the pathogenic effect and severity of infection. In this study, all the patients with polymicrobial growth and with a quantitative count of $\geq 10^{4} \mathrm{cfu} / \mathrm{gm}$ (5 of 41 patients; 12.2\%) developed post-operative infection on follow up. [Table 3]. Ikem et al has proposed the same fact in his study that polymicrobial growth of organisms are more virulent than the growth of a single bacterium. Also in tissues with mixed Gram negative and Gram positive flora there is an increased risk of infection, since the presence of the Gram positive organisms markedly increases the infection rate with the Gram negative organisms. ${ }^{10,11}$

Post operative follow up was done for 6 weeks. $46 \%$ of patients showed clinical signs of infection. $39 \%$ of patients turned out to be culture positive confirming the presence of post-operative infection.

The $66 \%$ culture positivity of the debridement samples could be attributed to the fact that quantitative bacterial count in the tissues are precise in predicting the risk of future infections. This was proved by Ramesh K Sen et al, who concluded in his study that skin samples may require bacterial contamination rate of $>10^{5}$ per gram of tissue to be infective whereas the presence of any bacteria in the muscle tissue at the end of debridement should be taken as a predictor of subsequent infection. ${ }^{12}$ Quantitative studies of biopsied wound specimens was further supported by Robson and Heggers et al, who argued that deep tissue biopsies are essential to quantify and determine the causative bacteria in a wound. ${ }^{13}$

\section{Conclusion}

Open fracture wounds are at a high risk of developing infections, as they are contaminated with a wide variety of microorganisms. Quantitative Microbiology plays a crucial role in the control of infection. A microbial load of $\geq 10^{4} \mathrm{cfu} / \mathrm{gm}$ of tissue is a definite forerunner for infection. Polymicrobial contamination of the wound in the debridement period has to be managed aggressively as persistence of the same can lead to infection in the postoperative period and may be detrimental to the clinical outcome.

\section{Financial Support: Nil}

\section{References}

1. Robson MC, Shaw RC, Heggers JP. Quantitative bacteriology and delayed wound closure. Surg Forum. 1968;19:501-502.

2. Breidenbach W.C, Trager S. Quantitative culture technique and infection in complex wounds of the extremities closed with free flaps. Plast Reconstr Surg. 1995;95(5):860-865.

3. Henry D. Isenberg, Lynne S. Garcia. Clinical Microbiology Procedures Handbook, 2nd ed. Washington, D.C: ASM Press; 2007.p: 3.13 .1

4. Levine, N. S., R. B. Lindberg, A. D. Mason, and B. A. Pruitt. The quantitative swab culture and smear: a quick simple method for determining the number of viable bacteria on open wounds. J. Trauma. 1976;16(2):89-94.

5. Clinical and Laboratory Standards Institute. Performance standards for Antimicrobial Susceptibility Testing, CLSI document M100S, $26^{\text {th }}$ ed. Pennsylvania, USA. 2016;36(1).

6. Patricia M. Tille. Bailey and Scott's Diagnostic Microbiology, 13th ed. Missouri: Elsevier; 2014.

7. Bowler P.G, Duerden B.I, Armstrong D.G. Wound Microbiology and associated approaches to wound management. Clinical Microbiology Reviews. 2001;14(2):244-269.

8. George W. Wood II. Campbell's Operative Orthopaedics, 12thed, Vol I. PA: Elsevier;2013. p:2561-2587.

9. Merritt. K. Factors Increasing the Rate of Infection in Patients with Open Fractures. J Trauma. 1988;28(823).

10. Ikem IC, Oginni LM, Bamgboye EA, Ako-Nai AK, Onipade AO. The bacteriology of open fractures in IleIfe, Nigeria. Niger J Med 2004;13:359-65.

11. Merritt K, Dowd JD. Role of internal fixation in infection of open fractures:Studies with Staphylococcus aureus and Proteus mirabilis. J Orthop Res. 1987;5:23-8.

12. Ramesh K Sen, Murthy NRS, Shivinder S Gill, and Onkar N Nagi. Bacterial load in tissues and its predictive value for infection in open fractures. India Journal of Orthopaedic Surgery. 2000;8(2):1-5

13. Robson, M. C. Wound infection. A failure of wound healing caused by an imbalance of bacteria. Surg Clin North Am. 1997;77:637-50.

How to cite this article: Arthi $K$, Deepa $R$, Mangala A. Quantitative bacteriology-A predictor of risk of postoperative infection in open fractures. Indian J Microbiol Res. 2018;5(3):421424.

\section{Conflicts of Interest: None}

